\title{
The Urgency of Handling Non-Performing Financing in Sharia Banks in the Development of Indonesian Sharia Economics
}

\author{
Renny Supriyatni ${ }^{*}$, Nurjamil $^{* *}$ \\ DOI: https://doi.org/10.22304/pjih.v8n1.a2
}

Submitted: September 28, 2020| Accepted: February 25, 2021

\begin{abstract}
In Indonesia, non-performing financing in Islamic banking has a significant impact on banking system, soundness level of bank, and national economy. Proper handling can minimize the risks so that Islamic banking can continue to develop. This study elaborated the urgency of handling problematic financing in Islamic banks in the development of the Indonesian Islamic economy. This study is a descriptive analytical study with a normative juridical approach. The data was analyzed juridically and qualitatively. Problematic financing in Islamic banks occurs due to internal and external factors. On the other hands, Islamic economy, including its handling methods, are guided by the Holy Quran and the hadiths of the Prophet Muhammad (Peace be Upon Him). The guidance are understood contextually. One of the ways is through restructuring. Handling problematic financing is a very important thing, not only in terms of the obligation to settle debts and receivables of a legal subject, but also closely related to the sustainability of the business of Islamic banks since it also has an impact on the development of the Islamic economy in Indonesia.
\end{abstract}

Keywords: Islamic banks, Islamic economics, problem financing.

\section{Urgensi Penanganan Pembiayaan Bermasalah pada Bank Syariah dalam Pengembangan Ekonomi Syariah di Indonesia}

\begin{abstract}
Abstrak
Pembiayaan bermasalah yang terjadi pada perbankan syariah berdampak cukup signifikan terhadap system perbankan, tingkat kesehatan bank, dan perekonomian nasional. Penanganan yang tepat dapat meminimalisir risiko yang terjadi sehingga perbankan syariah dapat terus berkembang. Penelitian ini dilakukan untuk mengelaborasi urgensi penanganan pembiayaan bermasalah pada bank syariah dalam pengembangan ekonomi syariah di Indonesia. Penelitian ini merupakan penelitian yang bersifat deskriptif analitis dengan metode pendekatan yuridis normatif dimana data dianalisis secara yuridis kualitatif. Pembiayaan bermasalah pada bank syariah terjadi karena factor internal maupun ekternal yang metode penanganannya dituntun di dalam al-Qur'an yang didukung oleh hadits-hadits Nabi yang difahami secara kontekstual dimana cara yang dilakukan adalah melalui

\section{PADJADJARAN Journal of Law Vol. 8 Number 1 Year 2021 [ISSN 2460-1543] [ISSN 2442-9325]}

* Lecturer, Researcher, and Chairperson of the Center for Islamic Law Studies, the Faculty of Law, Universitas Padjadjaran, Jl. Dipatiukur No. 35 Bandung, S.H. (Universitas Padjadjaran), M.H. (Universitas Padjadjaran), Dr. (Universitas Padjadjaran), renni@unpad.ac.id

** Lecturer of Business Law and Sharia Arbitration at the Sharia Economics Study Program, IKOPIN, JI. Jatinangor KM 20,5 Sumedang, S.H.I. (UIN Syarif Hidayatullah), M.H. (Universitas Padjadjaran), nurjamil@ikopin.ac.id
\end{abstract}


restrukturisasi. Penanganan pembiayaan bermasalah merupakan satu hal yang sangat penting, bukan hanya dari sisi kewajiban penyelesaian utang piutang seorang subyek hukum, akan tetapi juga erat kaitannya dengan keberlangsungan usaha bank syariah yang juga berdampak pada pengembangan ekonomi syariah di Indonesia.

Kata kunci: bank syariah, ekonomi syariah, pembiayaan bermasalah.

\section{A. Introduction}

Islamic Sharia has a very broad and comprehensive scope (al-syumul). It contains the regulation of all aspects of life, starting from the aspect of worship (human relationship with God), family aspects (such as marriage, divorce, living, will, and inheritance), business aspects (trade, industry, banking, insurance, accounts payable, marketing, and grants), legal and judicial aspects, to relations between states. ${ }^{1}$ Islamic sharia at the practical level then plays a role in the basis for the actions of legal subjects with the existence of sharia principles ${ }^{2}$ that provide guidance in all activities, including in economic activities, including banking activities.

The application of sharia principles, known as anti-maghrib (maisyir, gharar, dzalim, and riba), in the banking world is implemented through agreements (contracts) justified by sharia, such as sale and purchase contracts in the form of murabahah, salam, istishna, profit sharing in the form of musyarakah and mudharabah and forms of services such as ijarah, wakalah, kafalah, hawalah, rahn and ujrah. The act of making a contract ${ }^{3}$, which is a written agreement between a Sharia (Islamic) Bank or Sharia Business Unit (UUS) and another party that contains rights and obligations for each party in accordance with Sharia Principles, is included in the classification of muamalah. ${ }^{4}$ The basic rule for muamalah is that everything is permissible unless there are arguments that explicitly forbid. The definition of sharia principles is generally stated in Article 1 Number (12) of the Law Number 21 of 2008 on Islamic Banking (the Law on Islamic Banking). ${ }^{5}$ Sharia principles, which are defined as principles of Islamic law in banking activities based on fatwas issued by institutions that have the authority to stipulate every fatwa in the field of sharia.

Ahmad Ifham Sholihin, Buku Pintar Ekonomi Syariah, Jakarta: Gramedia Pustaka Utama, 2010, p. 809.

Sharia principles are rules of agreements based on Islamic law between banks and other parties to deposit funds and/or finance business activities, or other activities declared in accordance with sharia, including financing based on the principle of profit sharing (mudharabah), financing based on the principle of equity participation (musyarakah), the principle of buying and selling goods by obtaining profit (murabahah), or financing capital goods based on the principle of pure lease without choice (ijarah), or with the option of transferring ownership of goods leased from the bank by another party (ijarah wa iqtina)

3 Sufiarina, "Lembaga Alternatif Penyelesaian Pembiayaan Bermasalah dalam Perbankan Syariah di Indonesia", A Paper in the One-day Seminar on Troubled Financing in Islamic Banking in Indonesia, Research Team of PUPT-PSHI FH Unpad, Friday, October 27, 2017, p. 1.

4 Neneng Hasanah and Hamzah, "Kaidah-kaidah Islam Menjawab Persoalan Sosial dan Ekonomi Umat", Assyari'ah, Vol. 21, No. 1, 2019, p. 44.

5 See Article 1 Number (12) of the Law Number 21 of 2008 on Islamic Banking. 
In the Elucidation of Article 2 of the Law on Sharia Banking, business activities based on Sharia Principles includes, but not limited to, business activities that do not contain the following elements.

1. Riba is an increase in income illegally (bathil, vanity). They are, among others, in the exchange of similar goods that are not of the same quality, quantity, and delivery time $(f a d h /)$, or in lending and borrowing transactions that require the Facility Recipient Customer to return funds received in excess principal of the loan due to the passage of time (nasi'ah).

2. Maisir covers transactions that are dependent on uncertain and chancy natures.

3. Gharar is a transaction on object that is unclear, not owned, its whereabouts are unknown, or cannot be submitted at the time the transaction is carried out unless otherwise stipulated in sharia.

4. Haram refers to transactions on objects are prohibited by sharia.

5. Zalim refers to transactions that cause injustice to certain parties.

These principles of sharia business must be in line with the principles of Islamic finance, which consist of the following. ${ }^{6}$

1. Prohibition on interest: interest or usury can be interpreted as any increase or increase in value/price imposed on "capital" either in loans or trading.

2. Risk sharing: investors and entrepreneurs share the risks of the economic activities being carried out.

3. Money as "potential" capital: money is considered as potential capital because it is said to be actual capital when used or combined with other "resources" in production activities.

4. Being speculative is business behavior that is prohibited.

5. Sanctity of contract in Islam is very respected. One of its forms is to enforce contractual obligations and provide correct information.

6. The implementation of economic activities must be in accordance with Sharia.

In the elucidation of Article 49 (i) of the Law Number 3 of 2006 on Amendments to the Law Number 7 of 1989 on the Religious Courts (UUPA), the sharia economy is an act or business activity carried out according to the principles of sharia that include

(1) Sharia Bank,

(2) Sharia microfinance institutions,

(3) Sharia insurance,

(4) Sharia reinsurance,

$6 \quad$ Renny Supriyatni, Sistem Bagi Hasil dengan Mekanisme Pembagian Untung Rugi (Profit and Loss Sharing Mechanism) dapat Memberi Keadilan bagi Nasabah \& Bank Syariah, Bandung: Unpad Press, 2010, p. 25. 
(5) Sharia mutual funds,

(6) Sharia bonds and medium term sharia securities,

(7) Sharia securities,

(8) Sharia financing,

(9) Sharia pawnshop, pension funds of sharia financial institutions, and

(10)Sharia business.

In practice, financing transactions in Islamic banking often do not run smoothly because there is one party who does not fulfill the obligations (default). The default often triggers a dispute between the parties who entered into the agreement (akad). Disputes involving Islamic economic institutions (Sharia Banking) mostly cover non-performing financing. The term is different from the one used in commercial banks, known as Non-Performance Loans (NPLs) or bad credit. ${ }^{7}$

Problematic financing that occurs in Islamic banking has an impact on the banking system, the soundness of the bank, and the national economy. This impact has an effect, including affecting profit-and-loss and liquidity-and-solvency. At a certain level, it even causes loss and bankruptcy. Problematic banks, under the supervision of the Financial Services Authority (OJK -Otoritas Jasa Keuangan) have an effect on bank activities and the domino effect of the banking system. This will disrupt the financial system, intermediation function, and the real sector. It may even cause a multi-factor effect on third party funds (possible rush), diminish customer confidence, and affect overall economic growth. ${ }^{8}$ Based on Regulation of Bank Indonesias, the soundness level of a banking institution is healthy if the NPF or NPL is below 5 percent. The latest data from the OJK, for example, recorded that as of July 2020, the total NPF of Islamic Commercial Banks (BUS -Bank Usaha Syariah) was at the level of 3.31\%, instead it decreased by 5 basis points (bps). In fact, the NPF of Sharia Business Units was at the level of 3.38\%, up 36 bps on an annual basis. ${ }^{9}$

Islamic banking as one of the sectors that is quite important in the national economy, more specifically in terms of the sustainability and development of the Islamic economy in Indonesia, has received serious attention from the government. Therefore, the handling of problematic financing of the Islamic banking financial industry is very important. Based on the description, some problems that were identified covering the view of Islamic economic law on problematic financing

\footnotetext{
$7 \quad$ Wulandari Kuswahariani (et.al), "Analisis Non Performing Financing (NPF) Secara Umum dan Segmen Mikro Pada Tiga Bank Syariah Nasional di Indonesia", Jurnal Aplikasi Manajemen dan Bisnis, Vol. 6, No. 1, 2020 , p. 27.

8 See Mahmoedin, Melacak Kredit Bermasalah, Jakarta: Pustaka Sinar Harapan, 2011, p. 111.

9 Maizal Walfajri, "Non Performing Financing (NPF) Bank Syariah Lebih Baik dari Bank Konvensional", https://keuangan.kontan.co.id/news/non-performing-financing-npf-bank-syariah-lebih-baik-dari-bankkonvensional, accessed on December 2020.
} 
encountered by Islamic banks and the urgency of handling problematic financing in Islamic banks in the development of Indonesian Islamic economic.

\section{B. About Sharia Economic Law}

Currently, Sharia Economics, which is also called Islamic Economics, attracts the attention of many circles, including academics and economic practitioners, because it has differences in overcoming economic problems based on the teachings of Islamic Sharia. ${ }^{10}$ Some experts argue that Islamic economics is part of a branch of economics in general but there are also those who argue that Islamic economics is an independent discipline. Sharia economics is one part of this aspect of Islamic religious life. Sharia economics, present in the realm of the national legal system, is an embodiment of the growing growth of thought and awareness to realize legal principles as an agent of development, agent of modernization, and law as a tool of social engineering. ${ }^{11}$ The objective and motivation of a Muslim in carrying out economic activities is to realize the benefit of humankind in this world and the hereafter.

In carrying out economic activities, humans as members of society need a pattern or rules that are similar with members of society in other areas. This is necessary to provide convenience and fairness in transactions, usually based on local knowledge and traditions, as well as the agreement of both parties. The need for a law that regulates and maintains community relations is beneficial for the common interest. Knowledge of a rule or law is obtained by how humans can study something with their minds, whether inspired by natural events or the knowledge contained in the holy book of a religion -in this case, the Islamic teachings. ${ }^{12}$ Laliwala states that the Islamic view of the notion of economy should not be separated from the general understanding of the economy itself, he further emphasizes that the law of Islamic economics remain the same; even the behavior of economic agents become moral and is not found to be selfish and self-given in the Islamic society. The centralization of Islamic values will not change the laws of science of economic. Islamic economics aims to operate the value system of Islam. This means that Sharia economics is a part of Islam as a religion.

The application of Islamic Sharia in the economic field must be seen as an integral part of the application of Islamic law in other fields because it aims to

10 Mochtar Naim, “Kompendium Himpunan Ayat-ayat Al Qur'an yang berkaitan dengan Hukum", Jakarta: Hasanah, 2001, p. 118; See Ahmad Rofiq, Hukum Islam Di Indonesia, Jakarta: PT. Raja Grafindo Persada, 2004, p. 3. See also Van Hoeve, Ensiklopedi Islam, Jakarta: Ichtiar Baru, 1991, p. 346; Habib Nazir and M. Hasanudin, Ensiklopedi dan Perbankan Syariah, Bandung: Kaki Langit, 2004, p. 543.

11 Suhartono, "Prospek Legislasi Fikih Muamalah dalam Sistem Hukum Nasional", www.badilag.net/data/ARTIKEL/, accessed on November 2020.

12 M. N. Siddiqi, Teaching Islamic Economics, Jeddah: Scientific Publishing Centre-King Abdulaziz University, 2005, pp. 6-7. See also Frank E. Vogel (et.al), Hukum Keuangan Islam, Konsep, Teori \& Praktek, translated by M. Sobirin Asnawi (et.al), Bandung: Nusamedia, 2007, p. 23. 
achieve the transformation of society from an old cultured society to one with an Islamic culture. Therefore, the Islamic values must be internal in people's lives. In other words, Islam has become the culture of society. In the economic field, it can be divided into three levels of application: (1) Islamic economic theory, (2) Islamic economic system, and (3) the economy of Muslims. The development of the Islamic economy in Indonesia still faces many shortcomings that includes Human Resources, services, and networks. However, it quite encourages and provides bright prospects for the future. This, among others, is marked by some achievements. ${ }^{13}$ First, it is marked by the increasingly vibrant studies of Islamic economics, both formally and informally. It is well done by students, lecturers, and scholars, even by the public. Second, Islamic economic institutions, which are the embodiment of Islamic economics are increasingly showing their strength, both in quality and quantity -for example Sharia Banking, Sharia Insurance, Sharia Pawnshop, Sharia Capital Market, and Sharia Hotels. Likewise, Amil Zakat Agencies and Institutions, Baitul Maal Wattamwil, and Sharia Cooperatives have started to develop.

\section{Procedure for Providing Sharia Financing}

Article 1 number 17, 18, and 19 of the Sharia Banking Law mentions the parties that contribute to the operation of a sharia bank. They are, among others as follows.

a. Depositors Is a customer who place funds in a Sharia (Islamic) Bank in the form of deposits based on a contract between the Islamic bank and the concerned customer.

b. Investor customers is a customer placing funds in a sharia bank in the form of an investment based on a contract between the sharia bank and the concerned customer.

c. Facility recipient customers are customers who obtain fund facilities or their equivalent based on sharia principles.

Sharia banking carries out the function of channeling funds stipulated in Article 23 of the Sharia Banking Law. The bank must have confidence in the willingness and ability of the prospective Facility Recipient Customer to pay off all obligations on time before the Sharia Bank distributes funds to the customer receiving the facility.

In conventional banking, financing is usually called credit, the term credit is unrecognized in Islamic banks because it has a different scheme from conventional banks in channeling funds to customers, namely in the form of financing. ${ }^{14}$ The Law Number 21 of 2008 on Sharia Banking, Article 1 number (25), explains that financing is the provision of funds or an equivalent bill in the form of

13 Didin Hafidhuddin, "Peran dan Urgensi Ulama Dalam Mendukung Ekonomi Umat", Paper presented at Seminar Nasional Eksistensi Lembaga Keuangan Syari'ah Dalam Peningkatan Kwalitas Ekonomi Umat, SM FE UNPAD Bandung, 20 Maret 2006, p. 1.

14 Ismail, Perbankan Syari'ah, Jakarta: Prenada Group, 2011 p. 103. 
1) Profit sharing transactions in the form of mudharabah and musyarakah;

2) Leasing transactions in the form of ijarah or lease purchase in the form of ijarah muntahiya bittamlik;

3) Sale and purchase transactions in the form of murabahah, salam, and istishna receivables; and

4) Lending and borrowing transactions in the form of qardh receivables and service leasing transactions in the form of ijarah for multi-service transactions.

Approval or agreement between Bank Syari'ah and/or Sharia Business Unit and other parties financed and/or provided with funding facilities are required to return the funds after a certain period of time in exchange for ujrah, without compensation, or profit sharing. The methods or procedures for Islamic banks to channel and manage financing to their customers can be seen in the following picture. ${ }^{15}$

Figure 1. Financing Management Process in Islamic Banking

\section{Financing Management Process}

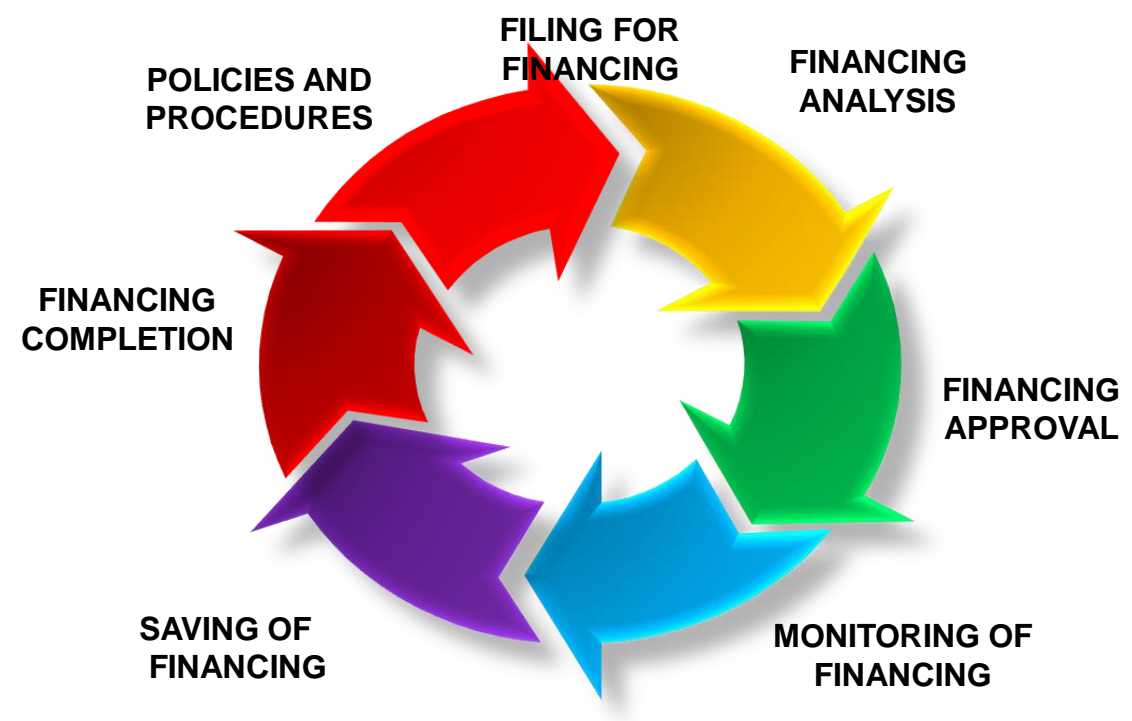

In addition to the figure, there also management process of sharia financing the basic principles of financing known as the $4 \mathrm{~T}$, fererring to tepat tujuan (right on

Hadi Purnomo, "Modul Executif Training, Restrukturisasi Pembiayaan Bermasalah Di Bank Syariah”, Iqtishad, Angkatan 138, Jakarta, June 25-27, 2015. 
purpose), tepat jumlah (right in amount), tepat pengembalian (right in return), and tepat ketentuan (right on provisions). The principles that have always been applied are the 6C, referring to Character (not blameless), Capacity (financial strength), Capital (equity as cushion), Condition of economic (implication of macroeconomic), Collateral (as second way out), and Control (adequate documentation).

\section{Financing Category}

The categorization of financing is based on the Decree of the Board of Directors of Bank Indonesia Number 31/147/KEP/DIR dated November 12, 1998, on Earning Asset Quality. They are as follows. ${ }^{16}$

\section{a. Pass}

Pass is financing where there are no arrears on margin or principal installments and the loan is not due or on time. Future payment of installments is expected to be current or on schedule without any doubt. A financing is current if it fulfills

1) payment of principal or interest installments on time;

2) having an active account mutation; and

3) Part of the financing that is secured by cash collateral.

\section{b. Special Mention}

Special mention is financing that shows a weakness in the debtor's financial condition or wealth. This is, for example, marked by a downward trend in profit margins and customer sales turnover affecting installment payments. Of particular concern is encountered when a condition meets the following criteria.

1) There are arrears in principal or interest installment payments that have not exceeded 90 days.

2) Overdrafts sometimes occur.

3) There are rarely any breaches of the contract agreed.

4) Account mutations are relatively active.

5) It is supported by new loans.

\section{c. Substandard}

Substandard is financing in which margin financing and principal installments may or have been disrupted due to unfavorable changes in terms of debtor finance and management, adverse economic or political policies, or very inadequate collateral. A substandard happens if the condition meets the following criteria.

1) There are arrears in principal or interest installments that have exceeded 90 days.

2) Overdrafts often occur.

3) There was a breach of the contract that was promised for more than 90 days.

16 See the attachment to Decree of the Board of Directors of Bank Indonesia Number31/147/KEP/DIR dated November 12, 1998 on Earning Assets Quality: Credit Quality Classification. 
4) The frequency of account mutations is relatively low.

5) There are indications of financial problems faced by debtors.

6) Weak loan documents.

\section{d. Doubtful}

Doubtful is financing in which the financing of all loans is beginning to be doubted so that it has the potential to cause losses to the bank. The size and timing cannot be determined. Careful and appropriate action must be taken to minimize losses. Doubtful happens when the condition meets the following criteria.

1) There are arrears in principal or interest installments that have exceeded 180 days.

2) There is an overdraft, which is permanent.

3) There is an achievement wan for more than 180 days.

4) There is interest capitalization.

5) There is weak legal documents, both for financing agreements and guarantee bonds.

\section{e. Loss}

Loss is a financing that is deemed uncollectible. The bank will bear the losses on the financing provided. Loss happens when the condition meets the following criteria.

1) There are arrears in principal or interest installments that have exceeded 270 days.

2) The operating loss is covered by a new loan.

3) From a legal standpoint and market conditions, guarantees cannot be cashed at fair value.

Financing is divided into non-problem financing and problematic financing, nonproblematic financing if it is included in the current category and with special attention. Problematic financing if it is included in the substandard, doubtful, and non-performing category.

\section{Non-Performing Sharia Financing}

Conventional banking use the term credit. Islamic banks does not recognize Credit because it has a different scheme from conventional banks in channeling funds to customers. The Law Number 21 of 2008 on Sharia Banking, Article 1 number (25), explains that financing is the provision of funds or an equivalent bill in the form of

1) Profit sharing transactions in the form of mudharabah and musyarakah;

2) Leasing transactions in the form of ijarah or lease purchase in the form of ijarah muntahiya bittamlik;

3) Sale and purchase transactions in the form of murabahah, salam, and istishna receivables; and 
4) Lending and borrowing transactions in the form of qardh receivables and service leasing transactions in the form of ijarah for multi-service transactions.

Approval or agreement involving Sharia Bank and/or Sharia Business Unit (UUS) and other parties financed and/or provided with fund facilities requires the other parties to return the funds after a certain period in exchange for ujrah, without compensation, or profit sharing. Furthermore, the sharia financing is not entirely carried out as promised, although various analyzes have been previously carried out. These procedures include juridical analysis, bank checking, character, finance, business analysis including the competence of prospective customers, conditions in similar business fields, macroeconomic, and collateral analysis. A deviation often occurs in the refund of financing which causes delays and/or a juridical action called potential loss is required. This financing condition is called problematic financing. Problematic Financing is a Financing condition, where there is a major irregularity in the repayment of financing, which causes delays in repayments, or juridical action is required in repayment or the possibility of potential loss. ${ }^{17}$

There are the efforts made by the bank in order to recover all receivables from customers or at least minimize the risk of loss that the bank may suffer. In other words, non-performing financing is financing that is under collectability under special attention, substandard, doubtful and loss, due to non-performing loans or non-performing finance. NPF can be said to be financing in which the collectability category is included in the criteria for substandard financing, doubtful financing, and non-performing financing.

Non-performing financing is one of the risks in the implementation of financing. Karim explains that financing risk is a risk caused by the existence of a counterparty in fulfilling its obligations. ${ }^{18}$ Non-performing financing is financing with payment quality that is in the substandard, doubtful and non-performing category. ${ }^{19}$ Nonperforming financing can be in the forms of non-current financing; financing where the debtor does not meet the promised requirements; financing that does not comply with the installment schedule; and financing that has the potential to harm creditors. ${ }^{20}$

\section{Factors Causing Problematic Financing}

Financing problems may not occur suddenly but it always gives a warning sign before, as previously described. The initial symptom of problem financing is characterized by management abnormalities, banking relationships, abnormal

\footnotetext{
17 Azman, Pembiayaan Bermasalah, Penyebab dan Cara Penanggulangannya, Jakarta: Muamalat Institut, no date, no page. See also Renny S. Bachro and Andi Fariana, Model alternative Mediasi Syariah Dalam Peneyelesaian Perbankan Syariah, Bogor: Mitra Wacana Media, 2016, pp. 41-45.

Adiwarman Karim, Bank Islam: Analisis Figh dan Keuangan, Jakarta: Rajagrafindo Persada, 2010, p. 260.

Suhardjono, Managemen Perkreditan Usaha Kecil dan Menengah, Yogyakarta: (UPP) AMP YKPN, 2003, p. 252.

Boy Leon and Sonny Ericson, Manajemen Aktiva Pasiva Bank Non Devisa, Jakarta: Grassindo, 2007, pp. 94-95.
} 
customer operational activities, and abnormal financial position. Non-performing financing in Islamic banking refers to the opinions of experts and experience. In principle the causes of problematic financing in banking can be divided into several factors as follows. ${ }^{21}$

a. Adversity is a change in the business cycle beyond the control of banks and customers, such as natural disasters, illness, and death.

b. Mismanagement is the customer's inability to manage their business activities and maintain their financial condition in accordance with healthy daily business activities.

c. Fraud is a debtor's dishonesty in providing information and reports on business activities, financial position, accounts payable, and inventory.

In the realization of a financing, there is an inherent risk, namely financing problems until the worst conditions become stuck. Marketing officer must consider the factors since they can affect the quality of the financing. They are as follows. ${ }^{22}$

a. Internal factors

1) Debtor is incompetent in business.

2) Management is not good or tidy.

3) Debtor has unclear financial reports.

4) The use of funds is not in accordance with the plan.

5) debtor has Inadequate planning.

b. External factors

1) The market aspect is less supportive.

2) People have poor purchasing power.

3) There are certain government policies.

4) External factor influences the business.

5) Debtor is delinquent.

The occurrence of problematic financing can be caused by many factors, both internal and external factors. According to Ascarya, the internal and external factors are as follows. ${ }^{23}$

$21 \quad$ Rizal Nur Firdaus, "Pengaruh Faktor Internal dan Eksternal Yang Mempempengaruhi Pembiayaan Bermasalah Pada Bank Umum Syariah di Indonesia", El-Dinar, Vol. 3, No 1, 2015, p. 165. Compare to Mares Suci Ana Popita, "Analisis Penyebab Terjadinya Non Performing Financing pada Bank Umum Syariah di Indonesia", Accounting Analysis Journal, AAJ, Vol. 2, No. 4, 2013, p. 411.

22 Muhammad, Manajemen Bank Syariah, Yogyakarta: UPP AMP YKPN, 2004, p. 269.

23 Ascarya, Akad dan Produk Bank Syariah, Jakarta: PT. RajaGrafindo Persada, 2008, p. 91; See Nurjamil, "Model Penyelesaian Sengketa Pembiayaan Bermasalah Pada Bank Wakaf Mikro Berbasis Pesantren", Res Nulius Law Journal, Vol. 1, No. 2, 2019, p. 88. 
a. Customer has weak characters. There are some examples of weak characters. First, customer does not want to or does not have good intentions. Second, customer loses business competition. Third, customer disappears.

b. Customer is careless. For instances, there are irregularities in the use of financing or the company is managed by an unprofessional family.

c. Customer has weak abilities. For instances, customer is unable to return financing due to disruption of business activity, lack of management capability, has outdated production techniques, inadequate marketing capabilities, limited or inadequate experience, and limited or inadequate information.

d. There are weaknesses in the analysis of financing. For examples, the analysis of financing is not based on accurate data or low data quality, incomplete financing information, inaccurate analysis, the financing period is too long, the financing period is too short, and the lack of accountability for financing decisions.

e. There are weaknesses in financing documents. The financing are not well documented; and supervision of physical documents is not implemented according to regulations.

f. There are negative economic situations like the economic crisis affecting currency exchange rate.

g. There are adverse domestic political situations, including the change of certain officials, diplomatic relations with other countries and social unrest.

h. There is adverse natural situations such as disasters that have negative effects on life.

\section{Non-Performing Financing Criteria}

The assessment of the quality of Sharia Financing is based on the ability to pay. It generally refers to the accuracy of installment payments. Based on the assessment, the collectability of Islamic financing consists of ${ }^{24}$

a. current collectability;

b. collectability in special mention;

c. substandard collectability;

d. doubtful collectability; and

e. loss collectability.

An overview of the assessment of the quality of Sharia Financing, which is carried out based on the ability to pay generally, refers to the accuracy of installment payments.

C. The Urgency of Handling Problematic Financing at Sharia Banks in the Development of Sharia Economics in Indonesia

24 Agustianto, op.cit. 
Non-Performing Financing (NPF) is the amount of financing classified as noncurrent with substandard, doubtful, and non-performing qualities based on the Regulation of Bank Indonesia Number 5/7/PBI/2003 on Earning Asset Quality for Islamic Banks. Non Performing Financings (NPFs) are non-current financing, ranging from substandard to non-performing. The term "problematic" 25 indicates a difficulty requiring a solution or an obstacle that interferes with the achievement of goals or optimal performance, or a deviation or mismatch between necessity and reality.

In handling Islamic banking's problematic financing appropriately, parties try to find a solution. Settlement of problematic Financing can be carried out in two stage categories, as follows.

\section{Troubled Financing Rescue Efforts}

The first stage is called rescue effort. In this stage it tends to be focused on efforts to achieve proper repayment of financing by means of cash collateral, rescheduling, reconditioning, or restructuring or the fulfillment stage of achievement. According to Kasmir, rescue of problem financing consists of several methods as follows. ${ }^{26}$

\section{a. Rescheduling}

\section{1) Extending the financing period}

In this case, debtor is given relief in the matter of the financing period, for example an extension of the financing period from 6 months to one year. Therefore, debtor has a longer time to recover.

\section{2) Extend the period of installments.}

This is almost the same as the financing period. In this case, the financing installment period is extended. For example, payments can be made from 36 times to 48 times. The number of installments also becomes smaller along with the increase in the number of installments.

\section{b. Reconditioning}

1) The postponement of the payment for the results up to a certain time means that it is only postponed for the results while the customer is only paying the principal first.

2) Abolition of profit sharing is given to customers with the consideration that the customer is no longer able to pay, but the customer still has an obligation to pay the principal until it is fully paid.

\section{c. Restructuring}

1) Bank increases credit/payment amount.

As Mahmoedin, Melacak Kredit Bermasalah, Jakarta: Pustaka Sinar Harapan, 2004, p. 6.

Kasmir, Bank dan Lembaga Keuangan, revised edition, Jakarta: Raja Grafindo Persada, 2008, p. 116. 
2) Bank increases equity, namely by depositing additional cash and cash from the owner.

\section{d. Combination}

Bank may also combine the three types of rescheduling, reconditioning, and restructuring methods.

\section{e. Foreclosure Guarantee}

Collateral confiscation is the last way if the customer really does not have good faith to pay off all his debts. ${ }^{27}$ When they were forced to do a confiscation, the confiscation was made to customers who were naughty and did not return their financing. However, it is still done in ways as taught in Islam, such as ${ }^{28}$

1) Sympathy: polite, respectful, and focused on the purpose of foreclosure;

2) Empathy: explore the customer's situation, speak as if it is the customer's interest, raise the customer's awareness to return the debt; and

3) Suppressing if the above two actions are not observed.

\section{Troubled Financing Settlement Efforts}

The second stage, financing settlement tends to focus on actions to seek repayment of financing by executing collateral, either by disbursing cash collateral, collecting to guarantor, taking over collateral by the bank, voluntary selling, or selling collateral through auction.

At this stage, efforts to resolve problematic financing in Islamic banking practices are carried out by, among others,

a. Settlement through internal institutions, by the account officer/remedial section formed by a task force to handle dispute resolution (Regulation of Bank Indonesia Number 5/7/PBI/2003 on Earning Asset Quality for Islamic Banks);

b. Settlement through banking mediation (Regulation of Bank Indonesia Number 10/1/PBI/2008 on Banking Mediation); and

c. Resolved through Arbitration/through the National Sharia Arbitration Board (Basyarnas) and/through the Religious Court (Article 55 of Law Number 21 on Sharia Banking).

In addition to the aforementioned problematic financing settlement efforts, one way of solving problematic financing with a group or collectability of nonperforming loans in Sharia Banks, according to Article 40 paragraph (1) of the Sharia Banking Law and Article 20 and Elucidation of Article 12 of Law Number 4 of 1996 on Mortgage, can be made through Foreclosed Collateral. 
Banks purchase debtor assets through the implementation of Foreclosed Collateral as an effort to resolve financing/bad credit at banks as regulated in the Elucidation of Article 12 of Law Number 4 of 1996 on Mortgage Rights. Holders of mortgage rights are prohibited from automatically becoming owners of the object of Mortgage Rights because the debtor is in default. In addition, guarantees in Islamic financial institutions are based on the DSN Fatwa Number 68/DSNMUI/III/2008 on Rahn Tasjily. It allows the guarantee of goods. In its development, the DSN Fatwa Number 92/DSN-MUI/IV/2014 on Financing with Rahn (Al-Tamwil Al-Mautsuq Bi Al-Rahn) emphasizes the permission to use collateral in the distribution of financing/funds to Islamic financial institutions as an obligation as a basis granting of facilities.

Efforts to overcome problematic financing include: ${ }^{29}$ (1) fines and compensation (ta'zir and $t a^{\prime}$ widh), (2) recovery and recovery of financing (revitalization), (3) financing settlement and off-set guarantee (voluntary submission of guarantees), (4) legal action, and (5) write off.

The definition of compensation $\left(T a^{\prime}{ }^{\prime} \text { idh }\right)^{30}$ is to cover losses that occur because of a violation or mistake. Compensation for delayed payments by people who can afford it is based on the real losses incurred as a result of delays in payments and the losses are a logical result of the late payments. The opinions of scholars regarding fines are as follows. ${ }^{31}$

a. Losses must be eliminated based on the rules of Sharia and such losses will not be lost unless replaced; while imposing sanctions (imprisoned) on capable debtors who delay payment will not provide benefits to the aggrieved creditors.

b. Postponement of payment of rights equals to ghashab. Therefore, the legal status should be the same, namely that the ghashab performer is responsible for the benefits of the object being ghasabed during the ghashab period, according to the majority of scholars, in addition he must also bear the price (value) of the item if it is damaged.

Sharia Fines is performed according to the hadith of the Prophet (PBUH) narrated by Nasa'i from Shuraid bin Suwaid, Abu Dawud from Shuraid bin Suwaid, Ibn Majah from Shuraid bin Suwaid, and Ahmad from Shuraid bin Suwaid. It reads that delaying (payments) made by people can justify their dignity and impose sanctions on them.

\footnotetext{
29 Fathurahman Djamil, Penyelesaian Pembiayaan Bermasalah di Bank Syariah, Jakarta: Sinar Grafika, 2012, pp. 75-77.

30 Wahbah al-Zuhaili, Nazariyah al-Dhaman, Damaskus: Dar al-Fikr, 1998, p. 87.

31 Fathul Aminudin Aziz, "Hukum Denda Dalam Keuangan Publik Islam di Indonesia", Al-Manahij, Vol. XII, No. 2, 2018, p. 326.
} 
The Fatwa Number 43/DSN/2004 on Compensation (Ta'widh) in the General Provisions reads as follows.

a. Compensation (ta`widh) may only be imposed on parties who deliberately or because of negligence do something that deviates from the provisions of the contract and causes losses to other parties.

b. The losses that can be subject to $t a^{\prime}$ widh as referred to in paragraph 1 are real losses that can be calculated clearly.

c. Real losses as referred to in paragraph 2 are real costs incurred in the context of claiming rights that should have been paid.

d. The amount of compensation (ta 'widh) is in accordance with the real loss value that must be experienced (fixed cost) in the transaction and not the loss that is expected to occur (potential loss) due to lost opportunities (opportunity loss or al-furshah al-dha-i'ah).

e. Compensation (ta 'widh) may only be imposed on transactions (contracts) that give rise to debts (dain), such as salam, istishna 'as well as murabaha, and ijarah.

f. In the Mudharabah and Musyarakah contracts, compensation may only be imposed by the shahibul mal, or by one of the parties in the musyarakah if the share of the profits is clear but not paid.

\section{The Urgency of Handling Problematic Financing}

Non-performing financing is principally an unpaid debt. In the realm of Islamic scholarship, there are several basic principles related to debt and credit as follows.

a. Debt must be differentiated into types, debt for consumption/living needs (alqardul Hasan) and debt for commercial business (murabahah, mudharabah, and musharakah).

b. Debt in all forms in Islam is in principle avoided, if any, it should be eliminated.

c. In business, mudaraba/musyarakah is recommended.

The Holy Quran, Chapter 2:280 regulates debts as follows.

"And if (the debtor) is in distress (if he will not be able to pay his debt), then let there be postponement until he is in ease. And for you to remit (it) as alms is better for you if you knew."

In addition, the Hadith also mentions as follows.

"Whoever gives a suspension to a person who is in trouble or frees him, surely Allah will protect him under His auspices." (Reported by Kaab bin Umar)

Based on the above verses and hadiths, it can be understood that the concept of Islamic economics provides a solution to handling problematic financing by providing deferral for debtors to fulfill their achievements. This study is on the 
position to view the above verses and hadiths to be understood as efforts to bring forth benefit as part of the manifestation of maqashidussyariah.

The context of the above verses and hadiths can be elaborated based on several rationale for interpretation as follows.

a. The context of this verse is actually tabarru (not for profit transactions), and not in the context of business/tijarah (for profit transactions). This is different from banking conditions, where the context is only business, not the tabarru.

b. Funds used by the creditor are his personal funds, not other people's/community funds. The funds used are funds entrusted by the public or ummah funds that must be protected from the risk of loss.

c. The number of depositor accounts is far more than the number of debtor accounts (around 13,100,000 versus 1,000,000). In general, banks collect funds from the wider community (retail funds), which are generally dominated by the middle to lower class (60\% are small people with a balance of Rp1 million and below) to be distributed to debtors, which are very small in number. To finance a debtor, a bank can take from hundreds of depositors. This general public fund really must be protected from injury and loss (maslahah hifzul mal). It is an important part of the maqashid of sharia.

d. Moral hazard generally lies on the side of the debtor, entrepreneur (mudharib), and not on the side of the depositor (shahibul mal). The way to settle the problematic debt is of course different from the textual meaning of Surah AlBaqarah 283.

Therefore, the settlement or handling of problematic financing is very important by looking at the broader context of the handling method as indicated in Surah AlBaqarah verse 283 and the hadith above. ${ }^{32}$

In the context of Islamic banking, particularly problematic financing, it is necessary to reinterpret religious texts relating to accounts payable to a more partial (maslahah) interest to depositors. In fact, the lower middle class practitioners of Islamic banking generally dominate them, especially by sharia banking regulators. Nevertheless, these religious texts are not placed in an appropriate context, used as an excuse by debtors to legitimize their moral hazard, and harm depositors who are representatives of the small community.

Restructuring is an effort made to manage and recover problematic financing, which still has prospects in its business and customers are experiencing a decline in capacity. It aims to

a. minimize the possibility of losses for banks,

b. rescue existing financing so that it becomes smooth, so that the quality of customer financing increases, and

32 See Fathurahman Djamil, op.cit; Agustianto, op.cit; Azman, op.cit. 
c. improve the quality of customers' businesses.

Financing Restructuring as an effort made by the Bank in order to assist and save customers in completing their obligations in three ways. Rescue and recovery (revitalization), carried out through, rescheduling, reconditioning, and restructuring.

The foundation of legal action can be found in the hadith narrated from Abu Hurairah. The Prophet (PBUH) says as follows.

"The soul of a believer is hanging in the sky because of his debt, until he is paid." (Narrated by At-Tirmidhi and Ibn Majah).

In another narration from At-Tirmidhi and Ibn Majah, the Prophet (PBUH) asked when a companion, "Does your friend have a debt?" They answered, "Yes, two dinars." Then the Prophet (PBUH) retreated saying, "Pray your friends!" Then Abu Qatada said, "The debt is my responsibility." Then the Prophet (PBUH) said "Fulfill (your promise)!" Then he prayed as follows

"For the sake of my soul that is in His Hands, if a man was killed (martyred) in the way of Allah, then he was brought back to life, then killed again (martyr), then revived and was killed again by martyrdom, (up to 3 times) while he was has a debt, really he will not go to Heaven until the debt is paid. " (Narrated by An-Nasa'i, Hasan).

From Shuhaib Al Khoir, the Prophet (PBUH) said,

"Whoever is in debt then intends not to pay it, then he will meet Allah (on the Day of Resurrection) as a thief." (HR. Ibn Majah no. 2410)

\section{Al-Munawi said,}

"People like this will be gathered together with the thief faction and will be rewarded just like them." (Faidul Qodir, 3/181)

Ibn Majah brought the above hadith in the point "Whoever is in debt and intends not to pay it." Based on the description above, the debt must be paid, because "Delaying payment for those who are able to pay is tyranny" (Narrated by Abu Hurairah). In addition, debt is required to pay debts, as the Prophet (PBUH) said, "Debt, for the sake of which I am under His control if a person dies in the way of Allah then he lives and dies again in the way of Allah and then lives again in the way of Allah he will not enter heaven until he pays his debt" (HR Ahmad).

In the context of sharia law and business, problematic financing should not occur if the parties prioritize the principle of good faith and adherence to sharia compliances with the prudential principle. From the perspective of Indonesia, as a legal state, the handling of problematic financing is closely related to law 
enforcement. Every contract made by the parties is a law that must be agreed upon. The pacta sunt servanda principle is the basis for the parties in the agreement to demand achievement and even suing other parties civil. In the business context, this greatly affects the sustainability of the banking business so that the national economy, especially in the Islamic banking sector, is more secure.

\section{Conclusion}

Problematic financing in Islamic banks occurs due to internal and external factors. The handling methods are based on the Holy Quran and the hadiths of the Prophet (PBUH). They must be understood contextually where the way is done is through restructuring. Handling problematic financing is a very important thing, not only in terms of the obligation to settle debts and receivables of a legal subject, but also closely related to the sustainability of the sharia bank business. It also has an impact on the development of the Islamic economy in Indonesia.

\section{References}

\section{Books}

Adiwarman Karim, Bank Islam: Analisis Fiqh dan Keuangan, Rajagrafindo Persada, Jakarta, 2010.

Ahmad Ifham Sholihin, Buku Pintar Ekonomi Syariah, Gramedia Pustaka Utama, Jakarta, 2010.

Ahmad Rofiq, Hukum Islam Di Indonesia, PT. Raja Grafindo Persada, Jakarta, 2004.al-Zuhaili, Wahbah, Nazariyah al-Dhaman, Dar al-Fikr, Damaskus, 1998.

As Mahmoedin, Melacak Kredit Bermasalah, Pustaka Sinar Harapan, Jakarta, 2004.

Ascarya, Akad dan Produk Bank Syariah, PT. RajaGrafindo Persada, Jakarta, 2008.

Azman, Pembiayaan Bermasalah, Penyebab dan Cara Penanggulangannya, Muamalat Institut, Jakarta, no year.

Boy Leon and Sonny Ericson, Manajemen Aktiva Pasiva Bank Non Devisa, Grassindo, Jakarta, 2007.

Fathurahman Djamil, Penyelesaian Pembiayaan Bermasalah di Bank Syariah, Sinar Grafika, Jakarta, 2012.

Habib Nazir and M.Hasanudin, Ensiklopedi dan Perbankan Syariah, Kaki Langit, Bandung, 2004. Hoeve, Van, Ensiklopedi Islam, Ichtiar Baru, Jakarta, 1991.

Ismail, Perbankan Syari'ah, Prenada Group, Jakarta, 2011.

Kasmir, Bank dan Lembaga Keuangan, revised edition, Raja Grafindo Persada, Jakarta, 2008.

, Dasar-Dasar Perbankan, Rajawali Pers, Jakarta, 2012.

Mahmoedin, Melacak Kredit Bermasalah, Pustaka Sinar Harapan, Jakarta, 2011.

Mochtar Naim, “Kompendium Himpunan Ayat-ayat Al Qur'an yang berkaitan dengan Hukum", Hasanah, Jakarta, 2001.

Muhammad, Manajemen Bank Syariah, UPP AMP YKPN, Yogyakarta, 2004. 
Renny S. Bachro and Andi Fariana, Model alternative Mediasi Syariah Dalam Peneyelesaian Perbankan Syariah, Mitra Wacana Media, Bogor, 2016.

Renny Supriyatni, Sistem Bagi Hasil dengan Mekanisme Pembagian Untung Rugi (Profit and Loss Sharing Mechanism) dapat Memberi Keadilan bagi Nasabah \& Bank Syariah, Unpad Press, Bandung, 2010.

Siddiqi, M. N., Teaching Islamic Economics, Scientific Publishing Centre-King Abdulaziz University, Jeddah, 2005.

Suhardjono, Managemen Perkreditan Usaha Kecil dan Menengah, (UPP) AMP YKPN, Yogyakarta, 2003.

Vogel, Frank E. (et.al), Hukum Keuangan Islam, Konsep, Teori \& Praktek, translated by M. Sobirin Asnawi (et.al), Nusamedia, Bandung, 2007.

\section{Other Documents}

Didin Hafidhuddin, "Peran dan Urgensi Ulama Dalam Mendukung Ekonomi Umat", Paper presented at Seminar Nasional Eksistensi Lembaga Keuangan Syari'ah Dalam Peningkatan Kwalitas Ekonomi Umat, SM FE UNPAD Bandung, 20 Maret 2006.

Fathul Aminudin Aziz, "Hukum Denda Dalam Keuangan Publik Islam di Indonesia", Al-Manahij, Vol. XII, No. 2, 2018.

Hadi Purnomo, "Modul Executif Training, Restrukturisasi Pembiayaan Bermasalah Di Bank Syariah", Iqtishad, Angkatan 138, Jakarta, June 25-27, 2015.

Maizal Walfajri, "Non Performing Financing (NPF) Bank Syariah Lebih Baik dari Bank Konvensional", https://keuangan.kontan.co.id/news/non-performing-financingnpf-bank-syariah-lebih-baik-dari-bank-konvensional.

Mares Suci Ana Popita, "Analisis Penyebab Terjadinya Non Performing Financing pada Bank Umum Syariah di Indonesia", Accounting Analysis Journal, AAJ, Vol. 2, No. 4, 2013.

Neneng Hasanah and Hamzah, "Kaidah-kaidah Islam Menjawab Persoalan Sosial dan Ekonomi Umat", Assyari'ah, Vol. 21, No. 1, 2019.

Nurjamil, "Model Penyelesaian Sengketa Pembiayaan Bermasalah Pada Bank Wakaf Mikro Berbasis Pesantren", Res Nulius Law Journal, Vol. 1, No. 2, 2019.

Rizal Nur Firdaus, "Pengaruh Faktor Internal dan Eksternal Yang Mempempengaruhi Pembiayaan Bermasalah Pada Bank Umum Syariah di Indonesia", El-Dinar, Vol. 3, No 1, 2015.

Sufiarina, "Lembaga Alternatif Penyelesaian Pembiayaan Bermasalah dalam Perbankan Syariah di Indonesia", A Paper in the One-day Seminar on Troubled Financing in Islamic Banking in Indonesia, Research Team of PUPT-PSHI FH Unpad, October 27, 2017.

Suhartono, "Prospek Legislasi Fikih Muamalah dalam Sistem Hukum Nasional", www.badilag.net/data/ARTIKEL/. 
Wulandari Kuswahariani (et.al), "Analisis Non Performing Financing (NPF) Secara Umum dan Segmen Mikro Pada Tiga Bank Syariah Nasional di Indonesia", Jurnal Aplikasi Manajemen dan Bisnis, Vol. 6, No. 1, 2020.

\section{Law Documents}

Law Number 21 of 2008 on Islamic Banking [Undang-Undang No. 21 Tahun 2008 tentang Perbankan Syariah].

Decree of the Board of Directors of Bank Indonesia Number 31/147/KEP/DIR dated November 12, 1998, on Earning Asset Quality [Surat Keputusan Direksi Bank Indonesia No. 31/147/KEP/DIR tanggal 12 November Tahun 1998 tentang Kualitas Aktiva Produktif]. 